\title{
Toricalogical assessment of Vernonia amygdaliana leaf meal in trition of starter broiler chicks
}

\author{
OE Fasina ${ }^{1}$, A.D Ologhobo ${ }^{2}$, G.A Adeniran ${ }^{3}$, G.O Ayoade $^{3}$, O.A Adeyemi ${ }^{1}$, \\ G Olayode ${ }^{4}$ and O.O. Olubanjo ${ }^{5}$
}

Dept of Animal Production Olabisi Onabanjo University

¿Dept. Of Animal Science, University of Ibadan

${ }^{3}$ Dept. of Vet. Medicine \& Vet Pathology. University of Ibadan

Dept. of Agricbusiness \& Farm Management., Olabisi Onabanjo university

${ }^{5}$ Dept. of Agric Economics, Olabisi Onabanjo University

\section{Abstract .}

In a 6-week feeding trial, Vernonia amygdaliana leaf meat (VaLM) was tested as a dietary ingredient in broiler starter diets. The diets comprised VaLM included at $O g$ (diet 1), $50 \mathrm{~g}$ per $\mathrm{kg}$ basal diet (incorporated at the expense of groundnut cake and wheat offals - diets 2 and 3 respectively) and $100 \mathrm{~g}$ per $\mathrm{kg}$ basal diet (incorporated at the expense of groundnut cake - diet 4). During the study, parameters such as characteristics, blood parameters, histopathology of some organs liver, kidney, lungs, heat, gizzard and pancreas' and carcass characteristics were investigated. Birds fed on $V a L M$ - based diets performed poorly, the effects of the diet being more pronounced on those fed diet 4. Addition of VaLM to poultry feed significantly $(P<0.05)$ reduced feed intake and weight gain of experimental birds. Blood cellular constituents decreased significantly $(P<0.05)$ in birds fed $V a L M$ - based diets and there were serious histopathological changes within the liver, kidney, lungs, heart, gizzard and pancreas.

Keywords: Vernonia amygdaliana leaf meal, starter broiler performance, histopathology.

\section{Introduction}

In Nigeria, feed cost is estimated to be over $70 \%$ of the total cost of production livestock intensive (Ogunfowora, 1984). This is due to the inavailability and steep rises in the prices of conventional feed ingredients, especially the energy and protein sources. A major solution to this problem is utilizing non-conventional sources of feed ingredients such as leafy plant, which can be incorporated into poultry diets. Although the protein from such leaves could be fed to farm animal in form of leaf protein concentrates (Farinu et al, 1992). This technology is not yet fully developed in Tropical Africa.
Several foliage portions of different plants have been used in poultry nutrition. These include the leaf meals of Adansonia digitat(Luru), Cynodon plectostachyum and Giant star grass (Ogunmodede and wogar, 1976), Leucaene (Taplin et al, 1981; Dada et al, 2000), Baobab (Ojabo and Njoku, 1986), Glyricidia sepium(cheeke and Rahanjo, 1987), Azolla and Banana plants (Cambel, 1989a,b), Cassava plant (Sanchez et al, 1986; Ogbonna and Oredein, 1998 Eruvbetine et al; 2003), Duckweed (Hanstein et al, 1994)wild sunflower (Odunsi et al, 1996), Water Hyacinth (Dairo, 1997) and Mimosa (Nworgu and Fapohunda, 2002) Which have been incorporate into poultry diets. 
Vernonia amvgdalina (bitter leaf) belong to the family composite. It grows throughout the tropics and it is an erect branches shrub or small tree (FAO, 1974). It is used in folk medicine and as a condiment in soup preparation. However, some antifeedants have been identified in the leaves(Jisaka et al, 1993; lgile et al, 1994). Reports on the feeding value of the plant for poultry are still scanty. In the light of the wide use of vernonia leaves for food purpose and folk medicine, this study was designed to evaluate the nutrition and toxicological implication of feeding Vernonia amygdalina leave to starter broiler chicks.

\section{Materials And Methods \\ Experimental Diets}

The VaLM (Vernonia amygdalina leaf meal) used in this study were harvested fresh from local farms in Nigeria, sun dried, milled and used in formulating the experimental diets for day-old broiler chicks (Tablel). All diets were made iso-nitrogeneous ( $23 \%$ Cnude protein) and iso-caloric $(2,900 \mathrm{kcalkg})$ Diet 1 (basal diet) served as the control. Each of the diets 2 and 3 contained $50 \mathrm{~g}$ ValMM $/ \mathrm{kg}$ basal diet incorporated at the expense of GNC and wheat offals respectively. Diet 4 contained $100 \mathrm{~g} \mathrm{VaLM} / \mathrm{kg}$ basal diet incorporated at the expense of GNC.

Table 1: Composition of VaLM-Based Diets ( $g$ kg-1)

\begin{tabular}{lcccc}
\hline \multirow{2}{*}{ INGREDIENTS } & \multicolumn{4}{c}{ DIETS } \\
\cline { 2 - 5 } & $\mathbf{1}$ & $\mathbf{2}$ & $\mathbf{3}$ & $\mathbf{4}$ \\
\hline Maize & 587.7 & 568.4 & 596.30 & 545.90 \\
Groundnut cake & 250.00 & 200.00 & 250.00 & 150.00 \\
Blood meal & 19.00 & 40.00 & 28.00 & 48.60 \\
Fish meal & 42.30 & 40.60 & 27.70 & 54.60 \\
Wheat offal & 50.00 & 50.00 & - & 50.00 \\
VaLM & - & 50.00 & 50.00 & 100.00 \\
Bone meal & 25.00 & 25.00 & 25.00 & 25.00 \\
Oyster shell & 10.00 & 10.00 & 10.00 & 10.00 \\
Palm oil & 3.00 & 3.00 & 3.00 & 3.00 \\
Salt & 3.00 & 3.00 & 3.00 & 3.00 \\
Vit/Min. Mix & 5.00 & 5.00 & 5.00 & 5.00 \\
Methionine & 3.00 & 3.00 & 3.00 & 3.00 \\
Lysine & 2.00 & 2.00 & 2.00 & 2.00 \\
Calculated Analysis: & & & & \\
Crude protein (\%) & 223.00 & 23.00 & 23.00 & 23.01 \\
M.E (kcal/g) & 2929.79 & 2894.30 & 2874.35 & 2854.72 \\
\hline \hline
\end{tabular}

\section{Birds and Management}

Ninety- six (96) day old chicks were randomly allocated to the four dietary treatments. Each treatment consisted of two replicates with twelve chick per replicate. The chicks were weighed at the beginning of the feeding trial and weekly thereafter. Feed and water were supplied ad libitum until the birds were six weeks old (i.e. end of grower phase). At the end of the feeding trial. blood were taken by cardiac puncture from eight birds chosen at random from each treatment.

Thereafter, the birds were fasted overnight and killed by cervical bone dislocation method. After defeathering and evisceration carcass characteristics such as the dressing and eviscerated carcass percentages were determined. The internal organ was dissected out after weighing and the liver. kidney, lungs. 


\section{Vernonia amygdaliana leaf in broiler diets}

hart gizzard and pancreas were preserved in $10 \%$ formalin solution prior to cutting. The ussue were trimmed and fixed in Bouin's fixative for 24hrs, embedded in wax and sectioned at $6 \mu \mathrm{m}$ nitha microtome and stained with haematoxylin and eosin (H and $E$ ) for histopathological examinations.

\section{Analytical Methods}

The test ingredient (VaLM) and theexperimental diets were analysed for their proximate constituents using the method of A.O.A.C(1990). Blood parameters were assessed using standard principles according to baker and Silverton (1985).

\section{Statistical Analysis}

Statistical analysis was carried out by analysis of variance according to simple classification model (Steel and Torric, 1980).

\section{Results}

Chemical Composition Of Dried VaLM.

The chemical composition of the dried sample of VaLM is presented in Table2. Dried VaLM on dry matter basis contained $20.99 \%$ crude protein, $8.93 \%$ crude fibre, $6.27 \%$ fat, $10.75 \%$ ash and $53.06 \mathrm{NFE}$

Table 2: Chemical Composition (\%DM) of VaLM

\begin{tabular}{ll}
\hline Parameters & Levels \\
\hline Dry matter & 91.00 \\
Crude protein (N\&6025) & 20.99 \\
Crude fibre & 8.93 \\
Fat & 6.27 \\
Ash & 10.75 \\
Reducing sugar & 5.45 \\
Phosphons & 0.26 \\
Magnesium & 0.35 \\
Calcium & 1.08 \\
Potassium & 2.88 \\
\hline
\end{tabular}

\section{Performance Characteristics}

Table 3 shows the influence of VaLM - based diet on the performance characteristics of the starter broiler chicks. Performances of broiler chicks were significantly different $(P<0.05)$ in terms of daily feed intake and weight gain. Addition of VaLM to poultry feed, irrespective of the level significantly $(\mathrm{P}<0.05)$ reduced feed intake and weight gain of experimental birds. The effect of the diet was most pronounced on birds fed diet 4 which contained $100 \mathrm{~g}$ VaLM/kg basal diets incorporated at the expense of GNC. Birds fed diet 4 gave the lowest daily feed intake value $(48.63 \mathrm{~g})$ and the poorest feed/gain ration of 2.80 .

Although the value obtained for the daily feed intake of birds on diet 2 was not significantly $(P<0.05)$ different from those fed diet 1 , the weight gain of these birds was significantly $(P<0.05)$ reduced. Mortality was recorded for experimental birds fed diet 4 . The average final weight at the end of the six weeks feeding trial ranged between $850.00 \mathrm{~g}$ and $1028.5 \mathrm{~g}$ with birds on the $100 \mathrm{~g}$ VaLM-based diet and control giving the lowest and highest gains respectively. 
Fasina,Ologhobo, Adeniran, Ayeade, Adeyemi, Olayode and Otbanjo

Table 3:Performance Characteristics of Starter Broiler Chicks Fed VaLM-Based Diets

\begin{tabular}{llllll}
\hline Characteristics & \multicolumn{5}{c}{ Diets } \\
\cline { 2 - 6 } & \multicolumn{1}{c}{1} & \multicolumn{1}{c}{2} & \multicolumn{1}{c}{3} & \multicolumn{1}{c}{4} & \pm SEM \\
\hline Initial live weight(g) & 48.50 & 50.00 & 50.00 & 49.50 & 0.31 \\
Final live weight (g) & $1028.50^{\mathrm{a}}$ & $1002.50^{\mathrm{a}}$ & $932.50^{\mathrm{b}}$ & $\mathbf{8 5 0 . 0 0 ^ { \mathrm { c } }}$ & 34.62 \\
Daily feed intake (g) & $57.76^{\mathrm{a}}$ & $53.08^{\mathrm{b}}$ & $52.98^{\mathrm{b}}$ & $48.63^{\mathrm{c}}$ & 1.06 \\
Weight gain (g) & $25.30^{\mathrm{a}}$ & $21.78^{\mathrm{b}}$ & $21.02^{\mathrm{b}}$ & $17.37^{\mathrm{b}}$ & 0.78 \\
Feed: gain ratio & $2.28^{\mathrm{c}}$ & $2.44^{\mathrm{bc}}$ & $2.52^{\mathrm{b}}$ & $2.80^{\mathrm{a}}$ & 0.50 \\
Mortality (\%) & $0.00^{\mathrm{b}}$ & $0.00^{\mathrm{b}}$ & $0.00^{\mathrm{b}}$ & $1.39^{\mathrm{a}}$ & 0.21 \\
\hline \hline
\end{tabular}

abc Means with different superscripts in a row differ significantly $(\mathrm{P}<0.05)$

\section{Blood Parameters}

Data on blood parameters as influenced by the diets are presented in Table 4 . There were significant $(\mathrm{P}<0.05)$ decreases in the values of red blood cell, packed cell volume, white blood cell and percentage neutrophils and a significant increase in percentage lymphocytes. The highest $(\mathrm{P}<0.05)$ percent hymphocyte was recorded for birds fed diet 4 . All the biochemical indices significantly $(\mathrm{P}<0.05)$ increased SGOT (Senum Glutamic Oxaloacetic Transaminase) activities. The least activities were obtained in the birds fed the control.

Table 4: Blood Constituents In Broiler Chicks Fed Val M-Based Diets

\begin{tabular}{|c|c|c|c|c|c|}
\hline \multirow[t]{2}{*}{ PARAMETERS } & \multicolumn{4}{|c|}{ DIETS } & \multirow[t]{2}{*}{$\pm \mathrm{SEM}$} \\
\hline & 1 & 2 & 3 & 4 & \\
\hline \multicolumn{6}{|l|}{ Haematological traits: } \\
\hline Packed cell volume (\%) & $32.53^{\mathrm{a}}$ & $26.13^{b}$ & $2501^{\mathrm{b}}$ & $23.86^{\mathrm{b}}$ & 0.87 \\
\hline Red blood cells $\left(\times 106 / \mathrm{mm}^{3}\right)$ & $2.67^{\mathrm{a}}$ & $2.18^{\mathrm{b}}$ & $2.10^{b}$ & $2.08^{b}$ & 0.14 \\
\hline White blood cell ( $\left.10 / \mathrm{mm}^{3}\right)$ & $53.58^{\mathrm{a}}$ & $37.15^{b}$ & $36.60^{b}$ & $31.45^{b}$ & 2.19 \\
\hline Lymphocytes (\%) & $72.50^{\mathrm{d}}$ & $77.50^{\mathrm{c}}$ & $79.00^{\mathrm{bc}}$ & $83.00^{\mathrm{a}}$ & 1.37 \\
\hline Neutrophils (\%) & $21.00^{\mathrm{a}}$ & $15.00^{\mathrm{b}}$ & $14.50^{b}$ & $11.00^{b}$ & 1.03 \\
\hline Monocytes (\%) & 2.00 & 1.00 & 1.00 & 0.50 & 1.25 \\
\hline Eosinophils (\%) & 3.00 & 5.00 & 5.00 & 5.00 & 0.55 \\
\hline Basophils (\%) & 1.50 & 1.50 & 0.5 & 0.50 & 0.25 \\
\hline \multicolumn{6}{|l|}{ Biochemical induces: } \\
\hline Total protein $(\mathrm{mg} / 100 \mathrm{ml})$ & $5.60^{\mathrm{a}}$ & $4.55^{\mathrm{b}}$ & $3.85^{\mathrm{bc}}$ & $3.60^{\mathrm{c}}$ & 0.19 \\
\hline Albumin (mg/100ml) & $2.16^{\mathrm{a}}$ & $1.83^{\mathrm{ab}}$ & $1.54^{\mathrm{bc}}$ & $1.39^{\mathrm{c}}$ & 0.90 \\
\hline Cholesterol (mg/dl) & $130.00^{\mathrm{a}}$ & $92.00^{\mathrm{b}}$ & $83.00^{\mathrm{c}}$ & $82.50^{c}$ & 0.90 \\
\hline Urea (mg/100ml) & $14.00^{\mathrm{a}}$ & $18.00^{\mathrm{a}}$ & $21.50^{\mathrm{A}}$ & $21.00^{\mathrm{a}}$ & 3.90 \\
\hline SGOT $(\mu / \mathrm{ml})$ & $143.0^{\mathrm{d}}$ & $152.00^{\circ}$ & $164.00^{\mathrm{b}}$ & $187.00^{\mathrm{a}}$ & 2.60 \\
\hline $\operatorname{SGPT}(\mu / \mathrm{ml})$ & $32.00^{\circ}$ & $51.00^{\mathrm{b}}$ & $56.00^{\mathrm{ab}}$ & $62.00^{\mathrm{a}}$ & 2.29 \\
\hline
\end{tabular}

abcd Mean with different superscript in a row differ significantly $(p<0.05)$ 


\section{Vernonia amygdaliana leaf in broiler diets}

\section{Histopathological Studies}

The result of histopathological changes are summarized in Table 5

i) Liver: Fatty liver syndrome was observed in chicks on diet 2 and focal necrosis in chicks on diet 4 .

ii) Kidney: Congestion of the kidney and slight heterophilic infiltration were observed in chicks maintained on diet 4. iii) Lungs: Congestion of the lungs was commonly observed in all chicks fed VaLM-based diets.

iv) Heart: Enlargement of this organ was observed only in birds on diet 4

v) Gizzard: Fat deposition on this organ was found in chicks fed diet 3 and 4

vi) Pancreas: Atrophy of this gland was found only chicks fed VaLM-based diets

Table 5:Histopathological lesions of organs in chicks fed VaLM-based diets

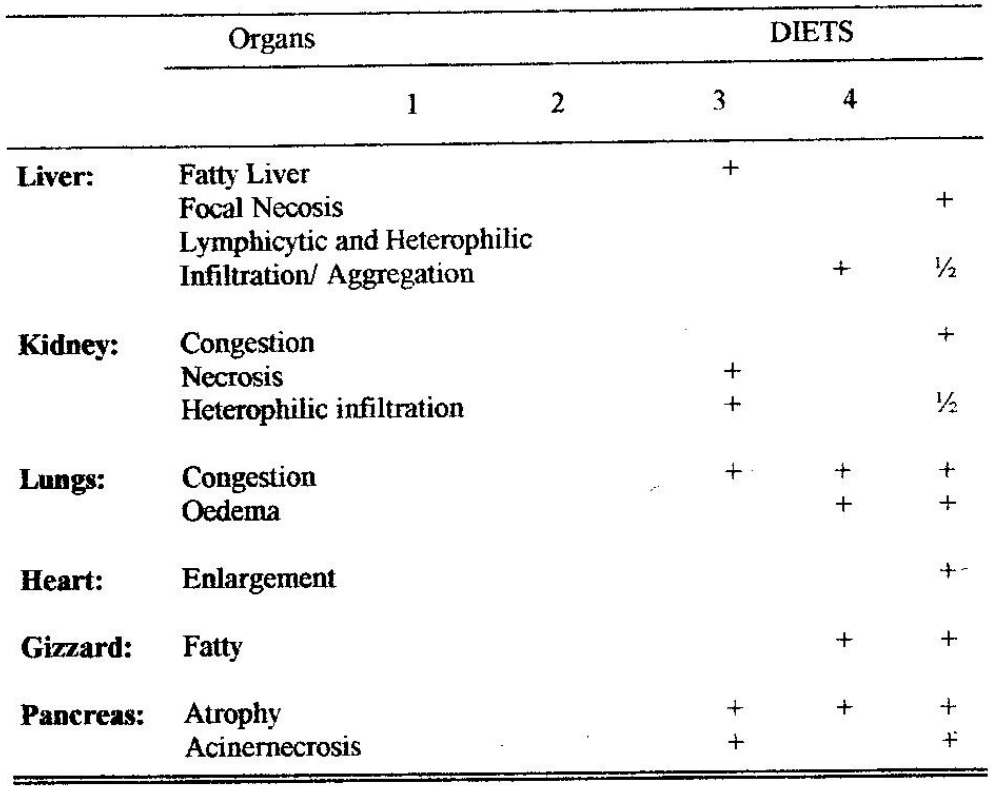

N.B: $t=$ present and distinct

$1 / 2=$ present but less marked than normal

Treatments with no sign indicated that no lesions were observed.

Carcass quality evaluation, abdominal fat and organ weights.

The data obtained for the carcass characteristics, lungs and gizzard among dietary treatments. abdominal fat and organ weights are sown in The liver decreased in size while the kidney Table 6 . The percent dressed carcass and percent increased but the diffenence between diets land eriscerated carcass values obtained for birds fed 2 were not significant. The weights of the VaLM - based diets were significant differences pancreas although not significant $(\mathrm{P}<0.05)$ $(\mathrm{P}<0.05)$ on the weights of the liver, kidney, increased with dietary treatments. 
Favina.Otoghobo, Adeniran. Ayoade. Adeyemi. Olayode and Olubanjo

Table 6: Dresing Proportions, Ihdominal Fat ind Organs Height of Starter Broller Chicks Fed falul-Based Diets

\begin{tabular}{|c|c|c|c|c|c|}
\hline \multirow[t]{2}{*}{ Parameters } & & & \multicolumn{3}{|c|}{ DIETS } \\
\hline & 1 & 2 & 3 & 4 & SEM \\
\hline Average live weight before slaughter & $889.46^{\mathrm{a}}$ & $852.3^{b}$ & $765.7^{c}$ & $677.53^{d}$ & 21.56 \\
\hline Dressing proportions (\% body weight) & & & & & \\
\hline Dressed carcass & $76.43^{\mathrm{B}}$ & $72.10^{\mathrm{b}}$ & $69.14^{b}$ & $63.86^{\mathrm{c}}$ & 3.76 \\
\hline Eviscerated carcass & $65.5^{\mathrm{a}}$ & $59.97^{\mathrm{b}}$ & $58.50^{\mathrm{b}}$ & $50.71^{\mathrm{c}}$ & 2.26 \\
\hline Total edible meat & $53.6^{\mathrm{a}}$ & $45.10^{b}$ & $43.25^{b}$ & $37.82^{c}$ & 1.52 \\
\hline Total bone & 12.24 & 11.62 & 11.48 & 10.45 & 0.44 \\
\hline Abdominal fat & $1.30^{\mathrm{c}}$ & $2.5 \mathrm{l}^{\mathrm{b}}$ & $2.63^{\mathrm{b}}$ & $3.78^{\mathrm{a}}$ & 0.19 \\
\hline Kidney & $1.02^{b}$ & $1.19^{\mathrm{b}}$ & $1.52^{\mathrm{a}}$ & $1.65^{a}$ & 0.4 \\
\hline Lungs & $0.44^{\mathrm{a}}$ & $0.38^{b}$ & $0.30^{\mathrm{c}}$ & $0.25^{\mathrm{d}}$ & 0.1 \\
\hline Gizzard & $2.10^{\mathrm{d}}$ & $2.63^{b}$ & $2.47^{\circ}$ & $2.78^{\mathrm{a}}$ & 0.4 \\
\hline Pancreas & 0.18 & 0.28 & 0.32 & 0.32 & 0.4 \\
\hline
\end{tabular}

${ }^{\text {abed }}$ Means with different superscripts in a now differ signification $(\mathrm{P}<0.05)$

\section{Discussion}

The values obtained for the chemical composition of dried VaLM in this study were similar to those reported by Igile et at (1995) except for the crude protein which was slight higher (20.99). They reported $18.38 \%$ crude protein.

From the results of the feeding trial with starter broiler chicks, it was observed that the inclusion of VaLM in broiler diets severely impaired growth and feed utilization. Although the amount of feed consumed by chicks in diets 2 and 3 were not significantly different, these values were below that obtained for birds fed the control diet. Starter broiler chicks fed diets 2 and 3 performed better than those fcid diet 4 . The fact that $100 \mathrm{~g}$ VaLM was incorporated in diet 4 probably accounted for the very poor performance and mortalities recorded in the chicks fed on this diet. The substitution of VaLM for groundnut cake and wheat offal significantly lowered weight gain of starter broiler chicks, indicating that VaL.M cannot be used to completely replace these two feed ingredients in diets of broilers. However, in the absence of methionine deficiency, the presence of anti-nutritional factors which are toxic and low protein digestibility are the main reasons claimed to explain the growth depression of birds on VaLM and these include some sigmastane-type steroidal saponins and these have been shown to have anti-feedant properties (Kamperdick et al, 1992; Igile et al, 1995). This observation agrees with the findings of Igile $e$ t al (1995) who reported a significant reduction in body weight gain of mice fed with standard diets containing $25 \%$ dry Vernonia amygdalina leaves or equivalent amount of alcohol extracts or crude or purified saponins in a 14 day feeding trial. However, this did not have any significant effect on the mice feeding performance. With respect to the blood constituents, the results obtained are in line with those of animals fed with saponin-containing diets. (Igile et al, 1995 ; Annongu et al, 1996). Even though the contents of the anti-feedant in VaLM were not analyzed, evidences from the result of the present study indicated that having consumed VaLM -based diets, the active principles in VaLM were released into the blood stream of the experimental birds and acted systematically to express their toxicity, hence the decreased PCV, $\mathrm{RBC}$ and WBC of these birds (George, 1965). The antifeedants in VaLM also acted on protein metabolism which in turn affected haematopoesis or indirectly on the blood 
chemistry to reduce the blood e (Asvalusa $e t$ al, 1073). Some ani-feedants (iike saponins) have also been reported to complex cholesterol and reduce its level (Topping et al, 1980). The reduction in neutrophils of birds fed VaLM bascd diets as compared to control might probably have been due to a response to accommodate more lymphocytes which were synthesized upon immunological induction. Coles (1977) described the immunological activity of lymphocytes following exposure to foreign compounds. Increased liver and serum transaminase activities are indications of liver damage (Rosalki and Wilkiron, 1976) and the significant increase $(P<0.05)$ in the activities of these enzymes in birds fed on VaLM - based diets indicates the toxic nature of Vernonia amygdalina. The reduction in carcass characteristics of birds fed VaLM- based diets indicated the prevalence of harzardous effect of the anti-feeding in VaLM following their cumulative intake in such dicts. The high abdominal fat of the birds fed on VaLM-based diets may be related to lipid synthesis and different in fat retention. It has been documented that saponins arresi growth by precipitating lipids or sterols in cell membrane (Reshef et al, 1976). The fibrous nature of VaLM-based diets probably led to the heavier gizzard weights. The overall result of this study suggest that the ability to incoporate VaLM in broiler diets will depend on evolving processing techniques that will reduce the concentration of the active ingredicnts in the leaves.

\section{References}

A.O.A.C. 1990. Official Method of Analysis, $15^{\text {th }}$ edition Association of official Analytical Chemist. Washington, D.C.

Annongu, A.A., Tre Meulen, U.Atteh, J.O and Apata, D.F. 1996. Toxicological assessment of native and industrial fermented sheabutter cake in nutrition of broilers. Archiv fur Geflugelk 50(5): 221226.
Assa. Y., Shany, S., Gesterner, B Tencer, Y., Birk, y. and Bondi, A. 1973. Alfalfa saponins $x$. interaction of alfalfa saponins with component of the erythrocyte membrane in heamolysis Biochem. Biophys. Acta 307: 83-91.

Baker F.J and Silverton, R.E. 1985. Introduction to Medical Laboratory Technology. $6^{\text {th }}$ ed. Butterwoth, England.

Cambel, 1.H. 1989a. Azolla meal;A potential protein feed for broilers. Proceesings of the third international conference on leaf protein Rescarch 1-7 October, Pisaperugia-viterbo, italy. P.170

Cambel, I.H. $1989 \mathrm{~b}$. Banana leaf meal for broiler productions of the third international conference on leaf protein Research 1-7 October, Pisa-Perugiaviterbo, italy. P. 171

Cheek, P.R. and Raharjo, Y.C. 1987. Evaluation of Glyricidia sepium forage and leafmeal as feedstuffs for rabbits and chickens. In: Washington, D., Glover, N. and Biewbaker, J.L.(eds). Glyricidia sepium (Jacq) Walp management and improvement. Nitrogen fixing tree Association, Waimanalo, H.I, USA. Pp 193-198.

Coles, M.J. 1977. Veterinary Clinical Pathology $4^{\text {th }}$ ed. Pp 40-48 (Philadelphia. saunderis).

Dada, S.A.O., Atada, L.A. and Alabi, B.E. 2002. Utilisation of leucaena leaf meal as a protein supplement in broiler finisher rations. Nig. J. Animal prod. 27(1): 40-44.

Dairo, F.A.S. 1997. Evaluation of water hyacinth (Eichhormia crassipes) as feed ingredient and yolk colouring agent in layers diets. Nig. I. Animal prod. 24(1): 43-45 
Eruvbatine D, Tajudeen L.D, A.T Adeosun, A.A. Olojede. 2003. Cassava (Manihot escnlenta) leaf and tuber conuntrate in diets for broiler chickens. Bioresource Tech 86:277-281.

Farinu G.O., Ajiboye, S.O and Aja, S. 1972. Chemical composition and nutritive value of leaf protein concentrate from Leucaena leuoocephala. J.Sc. Food Agric. 59:127129.

F.A.O. 1974. Growing Native vegetable in Nigeria. Pp99-100.

George. A.J. 1965. Legal status and toxicity of saponins. Fd. Cosmet. Toxicol. (3): 85-91.

Hausein, A.T. G; Man, R.H., skilicorn, P.W., Hannan, H., Diaz, F., Guevara, V., vergara, V., Gastanaduy, A. and Gilmar, J.B. 1994. Performance of broiler chickens fed diets containing duckweed (Lemna gibba). J. Agric. Science. Cambridge, 122:285-289.

Igile, G.O., Oleszek, W., Jurzysta, M., Burda, S., Fafunso, M. and Fasanmade, A.A. 1994. Flavonoids from Vernonia amygdaliana and their antiocxidant activity. J. Agric. Food chem. 43:24452448

Igile, G.O., Oleszek, W., Burda, S. and Jurzaysta, M. 1995. Nutrition assessment of Vernonia amygdaliana leaves in growing mice. I. Agric. Food chem. 43:2162-2166.

Jisaka, M., Ohigashi, H., Takegawa, K., Firota, M., Irie, R., Huffiman, M.A. and koshimizu, K. 1993. Steroid g;ucosides from Vernonia amygdaliana, a possible chimpanzee medical plant. Phytochem. 43:409-413).
Kamperdick, C., Breitmaier, I. and Radlof, M.A. 1992. A new steroid saponin from Vernonia amygdalina Del. (compositae). J. Prakt. Chem. 334: 425- 428.

Nworgo, F.C. and Fapohunda, J. B. 2002. Performance of broiler chicks fed mimosa (Mimosa invisa) leaf meal supplements. In proc of the $28^{\text {th }}$ Annual conference. NSAP, Fed. Univ. of Tech., Akure, Nigeria, March 172:2002.Pp.128-131

Odunsi, A.A., Farimu, G.O. and Akinola, J.O. 1996. Influence of dietary wild Sunflower (Lithonia diversifolia Hemsp. A Gray) leaf meal on layer performance and egg quality. Nig. J. Anim. prod. 23 (i): 2832.

Ogbonna, J.U. and Oredein, A.O. 1998. Growth performance of cockerel chicks fed Cassava leaf meal. Nig. J. Anim. prod. 25(2): 129- 133 .

Ogunfowora, O. 1984. "Structure, costs and Rations in Feedmill." Paper present at the Feed mill Management training Workshop, Dept of Agriculture Economics, University of Ibadan, Nigeria (April 10-May2, 1984).

Ogunmodede, B.K. and Wogar, G.L.S. 1976. The carotene vitamin. A and yolk colour of eggs from hens fed pasture spp. Nig. Agric. J. 8(2) :163-168.

Ojabo, L.D. and Njoku, P.C. 1986. Evaluation of baobab (Adansonia digitata) leaf meal as an egg yolk pigmenter. In: Proc. Of the $11^{\text {th }}$ Annual Conf., NSAP, Ahmadu Bello univ., Zaria, March 23-27:116-119.

Reself, G., Gestetner, B., Birk, Y. and Bondi, A. 1976. Effect of alfalfa saponins on the growth and some aspects of lipid metabolism of mice and quails. $J$. Sci. Food Agric 27:63-72. 
S. B. and Wilkiron, J.H. 1976. The i.ciples and practice of diagnostic -xmology. Arnold, London Pp 161-176.

Suren, J.J, Vargas, R., Montilla, J.J., Cieccia, A.M. and Brito, O. 1989. Partial sabstitution of sorghum and soybean meal b. cassava foliage in avian diets. Proc. $3^{\text {rd }}$ Inter. Conf. On leaf protein Research; 1-7 Oct., Pisa-Perrugia-Viterbo, Italy, Pp 124126.

Steel, R.G.D. and Torrie, J.H. 1980. Principles and Procedure of statistics: A Biometrical Approach, $2^{\text {nd }}$ ed, McGrawHill Book Co. Inc., New York.
Taplin, D.E., D'Mellow, D.P.F. and Phillips, P. 1981. Evaluation of Leucacna leaf meal from malawo as a source of xantophylls for the laying hen. Trop. Sci. 23:217-226.

Topping, D.L., Storer, G.B., Illman, G.D., Oakenfull, R.J., and Weller, R.A. 1980. Effect of dietary saponins on faecal bile acids aneutral sterols, plasma lipids and lipoproteri turnover in the pig. Anim. $J$. Clin. Nutri. 33: 783-786

Received 09 September 2002; Accepted 12 September 2003) 